\title{
Molecular basis of mouse developmental mutants
}

\author{
Alastair D. Reith ${ }^{1,3}$ and Alan Bernstein ${ }^{1,2}$ \\ ${ }^{1}$ Division of Molecular and Developmental Biology, Samuel Lunenfeld Research Institute, Mount Sinai Hospital, Toronto, \\ Canada M5G 1X5; ${ }^{2}$ Department of Molecular and Medical Genetics, University of Toronto, Toronto, Canada
}

Throughout this century, the characterization of phenotypic variants of the mouse has played an invaluable role in the establishment of mammalian genetics and in furthering our understanding of embryology and the cellular mechanisms underlying mammalian development. Until very recently, molecular characterization of these mutants was hampered by the size and complexity of the mouse genome and by the difficulties in translating complex developmental phenotypes into feasible cloning strategies. With recent advances in recombinant DNA technology and improvements in genetic and physical mapping methodologies, the molecular definition of this large collection of mutants is now possible.

Two broad genetic strategies have been taken to understand mammalian development at the molecular level (Table 1). Genes that may play critical roles in murine development have been identified by (1) cloning murine homologs of genes essential for normal development in other organisms (for reviews, see Holland and Hogan 1988; Kessel and Gruss 1990), (2) identifying genes involved in cellular proliferation and tumorigenesis (for reviews, see Adamson 1987; Mercola and Stiles 1988; Boettiger 1989), and (3) screening techniques based on differential expression patterns in the embryo (Allen et al. 1988; Kothary et al. 1988; Gossler et al. 1989). The roles played by such genes in mammals have been largely inferred from the biochemical properties of their protein products, their expression patterns in the developing embryo, and by extrapolation from the available genetic evidence of their homologs in other experimental systems, particularly Drosophila melanogaster. Direct genetic analysis of the function of such genes in mammalian development is now possible by generating gain or loss of function of mutations through the random or targeted insertion of exogenous DNA into the mouse germ line (for reviews, see Jaenisch 1988; Capecchi 1989; Rossant and Joyner 1989; Westphal and Gruss 1989).

A second and complementary approach is provided by the molecular analysis of existing mouse mutants (Table 1). Many of the 1300 or so genetic loci currently mapped in the mouse were identified originally on the basis of a mutant developmental phenotype (Lyon and Searle

${ }^{3}$ Present address: Ludwig Institute for Cancer Research, London W1P 8BT, UK.
1989). This collection of "classic" mutants has been recently augmented by the use of highly efficient chemical mutagens (for review, see Rinchik 1991) and by the production of insertional mutations by transgenic techniques. The rapid increase in the number of cloned genes, coupled with improved genetic and physical mapping techniques (Taylor 1978; Avner et al. 1988; Schlessinger 1990; Copeland and Jenkins 1991), has made the molecular definition of such mutant mouse strains an attainable goal.

Table 1. Molecular genetic analysis of mammalian development

\section{A. Genotype $\rightarrow$ phenotype}

1. Homologs of genes implicated in other developmental systems

2. Genes involved in cellular proliferation and tumorigenesis

3. Screens based on differential gene expression in the embryo

4. Generation of novel germ-line mutations in cloned genes

i. Gain-of-function/dominant-negative transgenes

ii. Gene targeting

iii. Cell ablation

iv. Antisense RNA

\section{B. Phenotype $\rightarrow$ genotype}

1. Spontaneous mutations

2. Radiation-induced mutagenesis

3. Chemical-induced mutagenesis

4. Transgene insertional mutagenesis

5. Molecular definition of mutant phenotypes

i. Association with previously cloned genes

ii. Physical mapping starting with closely linked marker

Two overlapping strategies are offered toward the further understanding of the molecular basis of development in the mouse. The first (genotype $\rightarrow$ phenotype) involves the isolation of potential development genes using a variety of criteria, followed by analysis of the phenotypic consequences of mutations in such genes by use of germ-line manipulation techniques. The second (phenotype $\rightarrow$ genotype) involves the utilization of existing, or generation of novel, mutant mouse strains that can then be defined either by association with a previously cloned gene or by physical mapping procedures (for examples, see text). 
In this review we consider some recent examples that serve to illustrate how molecular analyses of existing mouse mutant stocks are providing insights into the developmental functions of a variety of growth factors, receptors, and putative or known transcription factors. This work is also revealing the domains and residues critical for in vivo functions of these protein families, providing models for the types of mutations that may be usefully employed in the generation of gain- or loss-offunction mutations in the mouse germ line. In addition, novel protein families essential for normal development are being identified on the basis of the phenotypic consequences of their mutation.

\section{Direct association of cloned genes with mutant loci}

The rapid increase in cloning and mapping of genes in both man and mouse is resulting in increasingly detailed genetic and physical linkage maps, providing cloned markers close to specific mutant loci. In some cases, a connection can be made between the phenotypic properties of the mutant locus and the known biochemical properties and/or expression pattern of a closely linked gene, providing a basis for further investigation of the relationship between the mutant locus and a candidate gene. A relatively large number of mutant loci have been successfully identified in this way (Table 2).

Table 2. Mouse mutant loci for which candidate genes have been identified

\begin{tabular}{|c|c|c|c|}
\hline Locus (name) & Mutated gene & $\begin{array}{l}\text { Cell types or stage of } \\
\text { development affected }\end{array}$ & Reference \\
\hline \multicolumn{4}{|c|}{ Direct association with cloned genes } \\
\hline$b$ (brown) & tyrosinase-related protein 1 & melanocytes & $\begin{array}{l}\text { Jackson et al. }(1990) ; \\
\text { Zdarsky et al. (1990) }\end{array}$ \\
\hline$c$ (albino) & tyrosinase & melanocytes & Kwon et al. (1987) \\
\hline$d w$ (Snell's dwarf) & pit-1 & anterior pituitary & $\begin{array}{l}\text { Camper et al. }(1990) ; \mathrm{Li} \text { et } \\
\text { al. (1990) }\end{array}$ \\
\hline ip (jimpy) & myelin proteolipid protein & axons in CNS & Dautigny et al. (1987) \\
\hline $\begin{array}{l}\text { mdx (X-linked muscular } \\
\text { dystrophy) }\end{array}$ & dystrophin & muscle fibers & $\begin{array}{l}\text { Hoffman et al. }(1987) ; \\
\text { Sicinski et al. (1987) }\end{array}$ \\
\hline op (osteopetrosis) & CSF-1 & osteoclasts, macrophages & Yoshida et al. (1990) \\
\hline Ph (Patch) & $\begin{array}{l}\text { platelet-derived growth } \\
\text { factor receptor } \alpha \text {-subunit }\end{array}$ & $\begin{array}{l}\text { melanoblasts, hematopoietic cells, } \\
\text { recessive embryonic lethal }\end{array}$ & Stephenson et al. (1990) \\
\hline rd (retinal degeneration) & cGMP phosphodiesterase & rod cells in retina & Bowes et al. $(1990)$ \\
\hline shi (shiverer) & myelin basic protein & axons in CNS and PNS & Readhead et al. (1987) \\
\hline Sl (Steel) & Kit ligand & $\begin{array}{l}\text { hematopoietic cells, germ } \\
\text { cells, melanoblasts }\end{array}$ & $\begin{array}{c}\text { Copeland et al. }(1990) ; \\
\text { Huang et al. }(1990) ; \\
\text { Zsebo et al. (1990b) }\end{array}$ \\
\hline spf (sparse fur) & ornithine transcarbamylase & $\begin{array}{l}\text { skin, hair, liver, colon, } \\
\text { intestine }\end{array}$ & Veres et al. $(1987)$ \\
\hline un (undulated) & $P a x-1$ & vertebral sclerotome & Balling et al. $\{1988\}$ \\
\hline $\begin{array}{l}\text { W (Dominant white } \\
\text { spotting) }\end{array}$ & c-kit & $\begin{array}{l}\text { hematopoietic cells, germ } \\
\text { cells, melanoblasts }\end{array}$ & $\begin{array}{l}\text { Chabot et al. (1988) } \\
\text { Geissler et al. }(1988)\end{array}$ \\
\hline \multicolumn{4}{|c|}{ Insertional mutagenesis } \\
\hline$d$ (dilute) & novel myosin heavy chain & melanocytes, neurological & Mercer et al. (1991) \\
\hline ld (limb deformity) & novel (formins) & $\begin{array}{l}\text { limb bones, kidney } \\
\text { development }\end{array}$ & Woychik et al. $(1985,1990)$ \\
\hline $\begin{array}{l}\text { Mov-13, (Moloney leukemia } \\
\text { virus-13) }\end{array}$ & $\alpha-1$ procollagen I & late gestation lethal & Schnieke et al. (1983) \\
\hline $\begin{array}{l}\text { Mov-34 (Moloney leukemia } \\
\text { virus-34) }\end{array}$ & novel (Mov34) & postimplantation lethal & $\begin{array}{l}\text { Soriano et al. (1987); Gridley } \\
\text { et al. (1990) }\end{array}$ \\
\hline Mpv17 & novel (Mpvl7) & adult kidney function & Weiher et al. $(1990)$ \\
\hline \multicolumn{4}{|c|}{ Physical mapping } \\
\hline$T$ (Brachyury) & novel (pme75) & $\begin{array}{l}\text { mesoderm formation, } \\
\text { notochord development }\end{array}$ & Herrmann et al. (1990) \\
\hline Tdy (Testis determining-Y) & novel (Sry) & testis determination & Gubbay et al. (1990) \\
\hline
\end{tabular}

Murine developmental loci for which mutated genes have been identified are shown. Molecular analyses of many other transgene insertional mutants have been initiated, but the gene products of such loci remain to be identified. Some are known to be allelic with previously identified loci, including downless (dl) (Shawlot et al. 1989), dystonia musculorum (dt) (Kothary et al. 1988), Purkinje cell degeneration (pcd) (Krulewski et al. 1989), extra toes (Xt) (Pohl et al. 1990), hotfoot (ho) (Gordon et al. 1990), pygmy (pg) (Xiang et al. 1990), and microophthalmia (mi) (J. Krakowsky and J. Lingrel, pers. comm.; H. Arnheiter, Y. Hara, L. Forrester, and A. Bernstein, unpubl.). Others, such as MyK103 (Wilkie and Palmiter 1987), symplastic spermatids (sys) (MacGregor et al. 1990), and $H \beta 58$ (Radice et al. 1991) represent novel developmental loci. An additional $S l$ allele has also been generated by transgene insertional mutagenesis (Keller et al. 1990). 
Mutations at the Dominant-white spotting $(W)$ locus (Little 1915) on chromosome 5, or the Steel (SI) locus (Sarvella and Russell 1956) on chromosome 10, result in similar phenotypes that can include severe macrocytic anemia, sterility, and coat color abnormalities. Transplantation, tissue chimera, and in vitro coculture assays have established that the cellular bases of $W$ and $S 1 \mathrm{mu}-$ tations are distinct: $W$ mutations act intrinsically within stem cells of hematopoietic and melanogenic lineages, whereas the $S 1$ defect acts within the microenvironment of such cells (Russell 1979; Silvers 1979).

Insight into the molecular basis of the $W$ and $S 1 \mathrm{mu}-$ tations was obtained with the finding that the receptor tyrosine kinase c-kit mapped to human chromosome 4 (Yarden et al. 1987) in a region syntenic with mouse chromosome 5, where the $W$ locus is located. Together with the known biology of $W$ mutants, this made c-kit a highly attractive candidate gene for the $W$ locus. This possibility was confirmed by showing extremely tight genetic linkage between $W$ and c-kit in interspecific crosses (Chabot et al. 1988; Geissler et al. 1988), and mutations affecting c-kit structure, expression, and/or function in all 11 independent $W$ alleles analyzed to date (Chabot et al. 1988; Geissler et al. 1988; Dubreuil et al. 1990; Nocka et al. 1990a; Reith et al. 1990; Tan et al. 1990).

The identification of $\mathrm{c}-\mathrm{kit}$ as the product of the $W$ locus strongly suggested that the $S 1$ locus may encode a ligand for the c-kit receptor (Chabot et al. 1988). Subsequently, a Kit ligand was identified (Flanagan and Leder 1990; Nocka et al. 1990b; Williams et al. 1990; Zsebo et al. 1990a). Cloning of this growth factor and subsequent analyses established that it does indeed map to the $S I$ locus and is rearranged or deleted in independent $\mathrm{SI}$ alleles (Anderson et al. 1990; Copeland et al. 1990; Huang et al. 1990; Martin et al. 1990; Zsebo et al. 1990b). Taken together, $W$ and SI mutant animals provide elegant genetic evidence for the roles played by Kit-mediated signal transduction pathways in the development of hematopoietic, melanogenic, and germ cell lineages. Questions regarding the function of the Kit signaling pathway remain, particularly in neural tissues where no phenotype is yet apparent in $W$ or Sl mutants despite expression of both receptor and ligand in these tissues (Matsui et al. 1990; E. Keshet et al., pers. comm.; B. Motro et al., in prep.).

Another example of the roles of growth factor-mediated signaling pathways in development is provided by the osteopetrotic (op) mutant mouse, in which skeletal defects result from a restricted capacity for bone remodeling due to an osteoclast deficiency (Marks and Lane 1976). A reduction in macrophage numbers has also been noted in this mutant, a consequence of a defective microenvironment rather than an intrinsic stem cell defect (Wiktor-Jedrzejczak et al. 1982; Marks 1984). The mapping of the macrophage growth factor CSF-1 close to $o p$ on chromosome 3 (Buchberg et al. 1989; Gisselbrecht et al. 1989) provided a suitable candidate gene for this mutant locus. Together with the absence of biologically active CSF-1 in op/op cells (Wiktor-Jedrzejczak et al. 1990;
Yoshida et al. 1990) and the identification of a frameshift mutation in the CSF-1-coding region in op mice /Yoshida et al. 1990), it is likely that the op phenotype results from a loss-of-function mutation in the CSF-1 gene.

Although the phenotype of $o p / C S F-1$ mutant animals is consistent with the known properties of CSF-1 for in vitro maturation of macrophages and osteoclasts, newborn op homozygotes appear normal and no placental defect is apparent despite high levels of CSF-1 and its receptor c-fms during placental development (Bartocci et al. 1986; Pollard et al. 1987; Arceci et al. 1989; Regenstrief and Rossant 1989|. A maternal supply of CSF-1, and increased levels of other cytokines in op/op cells and tissues (Wiktor-Jedrzejczak et al. 1990), may compensate to some extent for the absence of embryonic CSF-1, thus minimizing the phenotypic consequences of the CSF-1 deficiency in op/op mice.

The candidate gene approach has also provided direct genetic evidence for the function of known or putative transcription factors in mammalian development. Mutations at the undulated (un) locus (chromosome 2) (Wright 1947) confer vertebral abnormalities over the entire length of the vertebral colunm, a consequence of perturbation in the position of the boundary between anterior and posterior sclerotome halves in the mid-gestation embryo (Gruneberg 1950, 1954). An understanding of the molecular basis of this mutant has been made possible by the mapping of the $\mathrm{Pax}-1$ gene to the un locus (Balling et al. 1988).

Pax-1 was isolated as a potential murine developmental control gene on the basis of its homology to the Drosophila paired-box, originally identified in a subset of segmentation genes known to play critical roles during Drosophila development (Bopp et al. 1986; Akam et al. 1987). The definition of mutations in Pax-1 gene structure or expression in three independent un alleles (Balling et al. 1988; Kessel and Gruss 1990), and the restriction of Pax-1 expression to posterior sclerotome halves during normal vertebra development (Deutsch et al. 1988), strongly implicate mutations in Pax-1 as playing a causal role in the generation of the un phenotype. Moreover, the phenotypic consequences of mutation of Pax-1 suggest that this putative transcription factor may play a directive role in sclerotome determination.

Like coat color or skeletal mutants, genetic dwarfism is one of the more easily assayed mutant phenotypes in mouse breeding stocks and a number of spontaneous dwarf mutant loci have been identified over the years. Two such mutants are Snell's dwarf $(d w)$ on chromosome 16 (Snell 1929) and Ame's dwarf (df) on chromosome 11 (Bartke 1964). Mice homozygous for either of these mutations have severely hypoplastic anterior pituitaries and are depleted in somatotroph, lactotroph, and thyrotroph cell types resulting from primary defects intrinsic to the pituitary (Carsner and Rennels 1960). The mapping of the POU domain-containing transcription factor pit-1 to chromosome 16 (Camper et al. 1990; Li et al. 1990) provided a suitable candidate gene for the $d w$ locus.

pit-1 was identified as a transcription factor that can 
trans-activate prolactin and growth hormone gene promoters and is restricted to the nuclei of somatotroph, lactotroph, and thyrotroph pituitary cell types (Bodner et al. 1988; Ingraham et al. 1988; Crenshaw et al. 1989; Mangalam et al. 1989; Simmons et al. 1990). The detection of genomic rearrangement of the pit-1 locus in the $d w^{J}$ allele, and point substitution of a highly conserved tryptophan residue within the POU domain of pit-1 in the original $d w$ allele ( $\mathrm{Li}$ et al. 1990), provides direct evidence that the $d w$ phenotype is a consequence of lossof-function mutations in the pit-1 transcription factor. Moreover, this analysis suggests that pit-1 is essential for the survival and/or proliferation of both lactotroph and somatotroph lineages, in addition to its putative role in mediating hormone expression in these cell types and, furthermore, indicates that pit-1 may also play a functional role in cells of the thyrotroph lineage.

\section{Physical mapping approaches}

An alternative to direct association of a candidate gene with a mutant phenotype is provided by the direct physical mapping and cloning of a mutant locus. The initiation of such an approach requires the availability of cloned markers that map close to the locus of interest. These can be provided in two ways.

\section{Insertional mutagenesis}

A number of mouse mutant phenotypes result from disruption of a functional transcription unit by either spontaneous or experimentally induced insertion of DNA elements into a functional locus. It is possible to use the insertional mutagenic element as a "cloning tag" to gain direct access to a mutant locus of interest (Table 2). Tags may take the form of spontaneous insertion of endogenous retroviral elements, as in the case of the dilute (d) (Jenkins et al. 1981; Copeland et al. 1983; Mercer et al. 1991), hairless (Stoye et al. 1988), and pink-eyed unstable (Brilliant et al. 1991) loci, or experimental introduction of ecotropic proviruses, as used to generate the Mov series of mutant mouse strains (Jaenisch 1976). In addition to these retrovirus insertional events, DNA microinjection into fertilized eggs has provided additional insertional mutagenic events at a frequency estimated to be as high as $5-10 \%$ (Jaenisch 1988). Although such tags can greatly facilitate the molecular definition of particular mutant loci, genomic rearrangements at the site of transgene integration (Covarrubias et al. 1986, 1987; Mahon et al. 1988) may complicate molecular analysis. Nevertheless, transgene insertions provide a powerful method of cloning developmentally important loci, as exemplified by the identification of the products of the mouse limb deformity (ld) locus (Cupp 1960).

$1 d / l d$ animals are characterized by fusions and reduction in the distal bones of the limbs that can be traced to a defect in limb bud development (Lyon and Searle 1989; Zeller et al. 1989). The molecular definition of the $1 d$ locus involved physical mapping and cloning approaches made possible by the fortuitous generation of novel $1 d$ alleles by insertional mutagenesis in a transgenic experiment (Woychik et al. 1985). Using the transgene as a "cloning tag," evolutionarily conserved coding sequences of the $1 d$ locus were cloned and found to encode a variety of novel proline-rich proteins, termed formins, produced from a family of differentially spliced, lowabundance mRNA species expressed in a wide variety of cell types (Zeller et al. 1989; Woychik et al. 1990). In two independent Id alleles, a common subset of formin mRNA species are not synthesized (Maas et al. 1990), indicating that functional disruption of the formin locus is causal in the generation of at least some $1 d$ alleles. The availability of the formin reagents, along with $l d$ mutant mice, will make it possible to analyze the functions of this complex family of proteins in limb morphogenesis.

\section{Walking to a mutant locus}

In the absence of an insertional cloning tag, the molecular definition of a mutant locus can be achieved only by direct physical mapping, cloning, and chromosome walking procedures. Such analysis is initiated by the use of the cloned markers nearest to the mutant locus; but despite the rapid increase in the number of cloned and mapped probes, markers may be a considerable distance from the locus of interest. A further limitation is imposed by the requirement for a large number of welldefined deletion and/or translocation mutant alleles to facilitate the construction of detailed physical maps of the mutant locus. Nevertheless, this approach has been successful in the identification of certain genes involved in human disease and embryological development (Lee et al. 1987; Riordan et al. 1989; Rommens et al. 1989; Bonetta et al. 1990; Call et al. 1990; Cawthon et al. 1990; Gessler et al. 1990; Sinclair et al. 1990; Viskochil et al. 1990). This strategy is also leading to the molecular cloning of murine developmental loci.

Mutations at the Brachyury (T) locus (chromosome 17) (Dobrovolskaia-Zavadskaia 1927) induce mild dominant defects in vertebrae development. $T / T$ homozygotes die at $\sim 10$ days of gestation, a consequence of a primary failure to produce sufficient mesoderm during primitive streak formation at $~ 7.5-8.5$ days of gestation (Chesley 1935; Yanagisawa et al. 1981). A large number of $T$ alleles bearing a variety of deletions and chromosomal breakpoints have been isolated in the past 50 years and have provided the basis for physical mapping of the $T$ locus to a 75-kb region of DNA (Herrmann et al. 1990). Within this region a single gene was identified, and conserved genomic fragments were used to isolate a cDNA clone of novel nucleotide sequence, pme75. Deletion of pme75-encoded sequences in many $T$ alleles and genomic rearrangement of pme75 in at least one $T$ allele $(H e r-$ rmann et al. 1990), coupled with the restricted expression of pme75 in target cell types of $T$ mutants /Wilkinson et al. 1990), strongly suggests that this cDNA clone represents a product of the $T$ locus and implicates this gene as playing a key role in mesoderm formation. The availability of the $T$ protein and $T$ mutant mice will fa- 
cilitate studies on the interactions between $T$ and other proteins involved in mesoderm formation (Rosa 1989; Mitrani et al. 1990; Smith et al. 1990; Thomsen et al. 1990), providing important insights into the molecular mechanisms involved in vertebrate mesoderm formation.

An elegant example of how human and mouse genetic analyses can be used in parallel to identify developmentally important genes is provided by the identification of the mammalian sex-determination gene. In man, analysis of sex-reversed individuals facilitated the construction of detailed genetic and physical maps restricting the testis-determining gene (TDF in human; $T d y$ in mouse) to a $60-\mathrm{kb}$ fragment of the $\mathrm{Y}$ chromosome. Within this region, a highly conserved $\mathrm{Y}$-specific gene, SRY, was identified (Sinclair et al. 1990). Further evidence supporting the notion that SRY is the mammalian sex-determining gene has come from the identification of point substitutions in SRY in some XY females that lack cytogenetic mutations in Y (Berta et al. 1990, Jager et al. 1990).

In the mouse, a number of mutations have been identified that result in sex-reversed phenotypes. The $S x r$ mutation (Cattanach et al. 1971) results in X/X or X/O individuals developing as males, a consequence of translocation of a small region of the $\mathrm{Y}$ chromosome to the distal end of $Y$ that undergoes recombination with $X$ during meiosis. A derivative mutant, $S x r^{\prime}$ (McClaren et al. 1984), is deleted for some genes translocated in Sxr but still gives rise to sex-reversed mice and so represents the smallest region of mouse $Y$ that contains $T d y$. Another sex-reversed mutant, $T d y^{\mathrm{ml}}$ (Lovell-Badge and Robertson 1990), produces XY females and can be complemented by $S \times r^{\prime}$, suggesting that this represents a lossof-function mutation in $T d y$. Consistent with the phenotypes of mouse sex-reversed mutants, the mouse homolog of $S R Y$ (Sry) was found to be present in the translocated region in $S X r$ and $S X r^{\prime}$ mutants but is deleted in $T d y^{m 1}$ mutants (Gubbay et al. 1990). Moreover, Sry is a member of a family of at least five closely related mouse genes, all of which contain sequences homologous to DNA-binding domains (Gubbay et al. 1990).

\section{Future prospects}

Developmental mutants in the mouse have played a key role in the establishment of mouse genetics and in the elucidation of developmental strategies in mammals. However, only within the last several years has it been possible to address the molecular bases of these mutant phenotypes. This analysis has already brought together proteins with well-defined biochemical properties and mutant strains that have been analyzed by genetic, cellular, and embryological approaches over many years. In addition, this genetic approach has led to the discovery of novel proteins that play key roles in development.

To date, only a very small proportion of the available mouse mutations have been accessed at the molecular level. As exemplified by $W$ and $S 1$ mutants, identification of the molecular defect in one mutant locus can facilitate the definition of other loci and also provide a basis for the generation of loss-of-function mutations in related proteins (A.D. Reith et al., in prep.) The continued cloning and mapping of novel genes and anonymous probes will provide ever more detailed genetic and physical maps of both human and mouse genomes. Coupled with the utilization of cloning vectors, such as yeast artificial chromosomes (Schlessinger 1990) and phage P1 vectors (Sternberg et al. 1990), the cloning of candidate genes for a given mutation by walking procedures should become a less formidable task than it is at present. Moreover, the development of techniques to introduce large DNA fragments into the mouse germ line (Richa and Lo 1989; Pavan et al. 1990) promises to provide a basis for genetic complementation assays to functionally define mutant loci, facilitating an entirely new strategy for cloning developmental genes in mammals. Over the next several years, this fusion of complementary genetic, biological, and biochemical approaches will undoubtedly lead to the molecular definition of many pre-existing mouse mutations. These approaches, coupled with genetargeting strategies to generate novel developmental mutants, will lead to a fuller understanding of the molecular mechanisms that regulate normal mammalian development.

\section{Acknowledgments}

We thank those who communicated results prior to publication and Janet Rossant for discussion. A.D.R. was supported by a NATO postdoctoral fellowship during part of this work. Work from the laboratory of A.B. is supported by grants from the Medical Research Council and National Cancer Institute of Canada and the National Institutes of Health.

\section{References}

Adamson, E.D. 1987. Oncogenes in development. Development 99: 449-471.

Akam, M. 1987. The molecular basis for metameric pattern in the Drosophila embryo. Development 101: 1-22.

Allen, N.D., D.G. Cran, S.C. Barton, S. Hettle, W. Reik, and M.A. Surani. 1988. Transgenes as probes for active chromosomal domains in mouse development. Nature 333: 852855.

Anderson, D.M., S.D. Lyman, A. Baird, J.M. Wignall, J. Eisenman, C. Rauch, C.J. March, H.S. Boswell, S.D. Gimpel, D. Cosman, and D.E. Williams. 1990. Molecular cloning of mast cell growth factor, a hematopoietin that is active in both membrane bound and soluble forms. Cell 63: 235-243.

Arceci, R.J., F. Shanahan, E.R. Stanley, and J.W. Pollard. 1989. Temporal expression and location of colony-stimulating factor 1 (CSF-1) and its receptor in the female reproductive tract are consistent with CSF-1-regulated placental development. Proc. Natl. Acad. Sci. 86: 8818-8822.

Avner, P., L. Amar, L. Dandalo, and J.L. Guenet. 1988. Genetic analysis of the mouse using interspecific crosses. Trends Genet. 4: 18-23.

Balling, R., U. Deutsch, and P. Gruss. 1988. undulated, a mutation affecting the development of the mouse skeleton, has a point mutation in the paired box of Pax-1. Cell 55: 531535. 
Bartke, A. 1964. Histology of the anterior hypophysis, thyroid and gonads of two types of dwarf mice. Anat. Rec. 149: 225 235.

Bartocci, A., J.W. Pollard, and E.R. Stanley. 1986. Regulation of colony-stimulating factor 1 during pregnancy. I. Exp. Med. 164: 956-961.

Berta, P., J.R. Hawkins, A.H. Sinclair, A. Taylor, B.L. Griffiths, P.N. Goodfellow, and M. Fellous. 1990. Genetic evidence equating Sry and the testis-determining factor. Nature 348: $448-450$.

Bodner, M., J.-L. Castrillo, L.E. Theill, T. Deerinck, M. Ellisman, and M. Karin. 1988. The pituitary-specific transcription factor GHF-1 is a homeobox-containing protein. Cell 55: 505-518.

Boettiger, D. 1989. Interaction of oncogenes with differentiation programs. Curr. Top. Microbiol. Immunol. 47: 31-78.

Bonetta, L., S.E. Kuhn, A. Huang, D.J. Law, L.M. Kallikin, M. Koi, A.E. Reever, B.H. Brownstein, H. Yaeger, B.R.G. Williams, and A.P. Feinberg. 1990. Wilm's tumor locus on $11 \mathrm{pl} 3$ defined by multiple $\mathrm{CpG}$ island-associated transcripts. Science 250: 994-997.

Bopp, D., M. Burri, S. Baumgartner, G. Frigerio, and M. Noll. 1986. Conservation of a large protein domain in the segmentation gene paired and in functionally related genes of Drosophila. Cell 47: 1033-1040.

Bowes, C., T. Li, M. Danciger, L.C. Baxter, M.L. Applebury, and D.B. Farber. 1990. Retinal degeneration in the $r d$ mouse is caused by a defect in the $\beta$ subunit of rod cGMP-phosphodiesterase. Nature 347: 677-680.

Brilliant, M.H., Y. Gondo, and E.M. Eicher. 1991. Direct molecular identification of the mouse pink-eyed unstable mutation by genome scanning. Science 252: 566-569.

Buchberg, A.M., N.A Jenkins, and N.G. Copeland. 1989. Localization of the murine macrophage colony-stimulating factor gene to chromosome 3 using interspecific backcross analysis. Genomics 5: 363-367.

Call, K.M., T. Glaser, C.Y. Ito, A.J. Buckler, J. Pelletier, D.A. Haber, E.A. Rose, A. Kral, H. Yeger, W.H. Lewis, C. Jones, and D.E. Houseman. 1990. Isolation and characterisation of a zinc finger polypeptide gene at the human chromosome 11 Wilm's tumor locus. Cell 60: 509-520.

Camper, S.A., T.L. Saunders, R.W. Katz, and R.H. Reeves. 1990 The pit-1 transcription factor gene is a candidate for the murine Snell dwarf mutation. Genomics 8: 586-590.

Capecchi, M.R. 1989. Altering the genome by homologous recombination. Science 244: 1288-1292.

Carsner, R.L. and E.G. Rennels. 1960. Primary site of gene action in anterior pituitary dwarf mice. Science 131: 829.

Cattanach, B.M., C.E. Pollard, and S.G. Hawkes. 1971. Sex reversed mice: $\mathrm{XX}$ and XO males. Cytogenetics 10: 318-337.

Cawthon, R.M., R. Weiss, G. Xu, D. Viskochil, M. Culver, J. Stevens, M. Robertson, D. Dunn, R. Gesteland, P. O'Connell, and R. White. 1990. A major segment of the neurofibromatosis type 1 gene: cDNA sequence, genomic structure and point mutations. Cell 62: 193-201.

Chabot, B., D.A. Stephenson, W.M. Chapman, P. Besmer, and A. Bernstein. 1988. The proto-oncogene c-kit encoding a transmembrane tyrosine kinase receptor maps to the mouse $W$ locus. Nature 335: 88-89.

Chesley, P. 1935. Development of the short-tailed mutant in the house mouse. J. Exp. Zool. 70: 429-459.

Copeland, N.G. and N.A. Jenkins. 1991. Development and application of a molecular genetic linkage map of the mouse genome. Trends Genet. 7: 113-118.

Copeland, N.G., K.W. Hutchison, and N.A. Jenkins. 1983. Excision of the DBA ecotropic provirus in dilute coat colour revertants of mice occurs by homologous recombination involving the viral LTRs. Cell 33: 379-387.

Copeland, N.G., D.J. Gilbert, B.C. Cho, P.J. Donovan, N.A. Jenkins, D. Cosman, D. Anderson, S.D. Lyman, and D.E. Williams. 1990. Mast cell growth factor maps near the Steel locus on mouse chromosome 10 and is deleted in a number of Steel alleles. Cell 63: 175-183.

Covarrubias, L., Y. Nishida, and B. Mintz. 1986. Early postimplantation embryo lethality due to DNA rearrangements in a transgenic mouse strain. Proc. Natl. Acad. Sci. 83: 60206024.

Covarrubias, L., Y. Nishida, M. Terao, P. D'Eustachio, and B. Mintz. 1987. Cellular DNA rearrangements and early developmental arrest caused by DNA insertion in transgenic mouse embryos. Mol. Cell. Biol. 7: 2243-2247.

Crenshaw, E.B, K. Kalla, D.M. Simmons, L.W. Swanson, and M.G. Rosenfeld. 1989. Cell-specific expression of the prolactin gene in transgenic mice is controlled by synergistic interactions between promoter and enhancer elements. Genes \& Dev. 3: 959-972.

Cupp, M.B. 1960. Mouse News Lett. 22: 50.

Dautigny, A., M.G. Mattei, D. Morello, P.M. Alliel, D. PhamDinh, L. Amar, D. Arnaud, D. Simon, J.-F. Mattei, J.-L. Guenet, P. Jollès, and P. Avner. 1986. The structural gene coding for myelin-associated proteolipid protein is mutated in jimpy mice. Nature 321: 867-869.

Deutsch, U., G.R. Dressler, and P. Gruss. 1988. Pax 1, a member of a paired box homologous murine gene family, is expressed in segmented structures during development. Cell 53: 617625 .

Dobrovolskaia-Zavadskaia, N. 1927. Sur la mortification spontanée de la queue chez la souris nouveau-nee et sur l'existence d'un caractere hereditaire "non-viable." C.R. Soc. Biol. 97: 114-116.

Dubreuil, P., R. Rottapel, A.D. Reith, L. Forrester, and A. Bernstein. 1990. The mouse W/c-kit locus: A mammalian gene that controls the development of three distinct cell lineages. Ann. N.Y. Acad. Sci. 599: 58-65.

Flanagan, J.G. and P. Leder. 1990. The kit ligand: A cell surface molecule altered in Steel mutant fibroblasts. Cell 63: 185194

Geissler, E.N., M.A. Ryan, and D.E. Housman. 1988. The dominant-white spotting $(W)$ locus of the mouse encodes the c-kit proto-oncogene. Cell 55: 185-192.

Gessler, M., A. Poustka, W. Cavanee, R.L. Neve, S.H. Orkin, and G.A.P. Bruns. 1990. Homozygous deletion in Wilm's tumors of a zinc-finger gene identified by chromosome jumping. Nature 343: 774-778.

Gisselbrecht, S., B. Sola, S. Fichelson, D. Bordereaux, P. Tambourin, M.-G. Mattei, D. Simon, and J.-L. Guenet. 1989. The murine M-CSF gene is localised on chromosome 3. Blood 73: $1742-1746$.

Gordon, J.W., J. Uehlinger, N. Dayani, B.E. Talansky, M. Gordon, G.S. Rudomen, and P.E. Neumann. 1990. Analysis of the hotfoot $(h o)$ locus by creation of an insertional mutation in a transgenic mouse. Dev. Biol. 137: 349-358.

Gossler, A., A.L. Joyner, J. Rossant, and W.J. Skarnes. 1989. Mouse embryonic stem cells and reporter constructs to detect developmentally regulated genes. Science 244: 463-465.

Gridley, T., D.A. Gray, T. Orr-Weaver, P. Soriano, D.E. Barton, U. Francke, and R. Jaenisch. 1990. Molecular analysis of the Mov 34 mutation: Transcript disrupted by proviral integration in mice is conserved in Drosophila. Development 109: $235-242$.

Gruneberg, H. 1950. Genetical studies on the skeleton of the mouse. II. Undulated and its "modifiers." $J$. Genet. 50: 142-173. 
1954. Genetical studies on the skeleton of the mouse. XII. The development of undulated. $I$. Genet. 52: 441-455.

Gubbay, J., J. Collignon, P. Koopman, B. Capel, A. Economou, A. Munsterberg, N. Vivian, P. Goodfellow, and R. Lovell-Badge. 1990. A gene mapping to the sex-determining region of the mouse $\mathrm{Y}$ chromosome is a member of a novel family of embryonically expressed genes. Nature 346: 245-250.

Herrmann, B.G., S. Labeit, A. Poustka, T.R. King, and H. Lehrach. 1990. Cloning of the $T$ gene required in mesoderm formation in the mouse. Nature 343: 617-622.

Hoffman, E.P., R.H. Brown, and L.M. Kunkel. 1987. Dystrophin: The protein product of the Duchenne muscular dystrophy locus. Cell 51: 919-928.

Holland, P.W.H. and B.L.M. Hogan. 1988. Expression of homeobox genes during development: A review. Genes \& Dev. 2: $773-782$.

Huang, E., K. Nocka, D.R. Beier, T.-Y. Chu, J. Buck, H.-W. Lahm, D. Wellner, P. Leder, and P. Besmer. 1990. The hematopoietic growth factor $\mathrm{KL}$ is encoded at the Steel locus and is the ligand of the c-kit receptor, the gene product of the $W$ locus. Cell 63: 225-233.

Ingraham, H.A., R. Chen, H.J. Mangalam, H.P. Elsholtz, S.E. Flynn, C.R. Lin, D.M. Simmons, L. Swanson, and M.G. Rosenfeld. 1988. A tissue-specific transcription factor containing a homeodomain specifies a pituitary phenotype. Cell 55: 519-529.

Jackson, I.J., D. Chambers, E.M. Rinchik, and D.C. Bennett. 1990. Characterization of TRP-1 mRNA levels in dominant and recessive mutations at the mouse brown $(b)$ locus. $G e$ netics 126: 451-459.

Jaenisch, R. 1976. Germ line integration and Mendelian transmission of the exogenous Moloney murine leukemia virus. Proc. Nat1. Acad. Sci. 73: 1260-1264.

- 1988. Transgenic animals. Science 240: 1468-1474.

Jager, R.J., M. Anvret, K. Hall, and G. Scherer. 1990. A human $X Y$ female with a frame shift mutation in the candidate testis-determining gene SRY. Nature 348: 452-454.

Jenkins, N.A, N.G. Copeland, B.A Taylor, and B.K. Lee. 1981. Dilute (d) coat colour mutation of $\mathrm{DBA} / 2 \mathrm{~J}$ mice is associated with the site of integration of an ecotropic MuLV genome. Nature 293: 370-374.

Keller, S.A, S. Liptay, A. Hajra, and M.H. Meisler. 1990. Transgene-induced mutation of the murine steel locus. Proc. Natl. Acad. Sci. 87: 10019-10022.

Kessel, M. and P. Gruss. 1990. Murine developmental control genes. Science 249: 374-379.

Kothary, R., S. Clapoff, A. Brown, R. Campbell, A. Peterson, and J. Rossant. 1988. A transgene containing lacZ inserted into the dystonia locus is expressed in neural tube. Nature 335: 435-437.

Krulewski, T.F., P.E. Neumann, and I.W. Gordon. 1989. Insertional mutation in a transgenic mouse allelic with Purkinje cell degeneration. Proc. Natl. Acad. Sci. 86: 3709-3712.

Kwon, B.S., A.K. Haq, S.H. Pomerantz, and R. Halaban. 1987. Isolation and sequence of a cDNA clone for human tyrosinase that maps at the mouse c-albino locus. Proc. Natl. Acad. Sci. 84: 7473-7477.

Lee, W.-H., R. Bookstein, F. Hong, L.-J. Young, J.-Y. Shew, and E.Y.-H.P. Lee. 1987. Human retinoblastoma susceptibility gene: Cloning, identification and sequence. Science 235: 1394-1399.

Li, S., E.B. Crenshaw, E.J. Rawson, D.M. Simmons, L.W. Swanson, and M.G. Rosenfeld. 1990. Dwarf locus mutants lacking three pituitary cell types result from mutations in the POUdomain gene pit-1. Nature 347: 528-533.

Little, C.C. 1915. The inheritance of black-eyed white spotting in mice. Am. Nat. 49: 727-740.

Lovell-Badge, R. and E. Robertson. 1990. XY female mice resulting from a heritable mutation in the primary testis-determining gene, Tdy. Development 109: 635-646.

Lyon, M.F. and A.G. Searle. 1989. Genetic variants and strains of the laboratory mouse, 2nd ed. Oxford University Press, Oxford.

Maas, R.L., R. Zeller, R.P. Woychik, T.F. Vogt, and P. Leder. 1990. Disruption of formin-encoding transcripts in two mutant $\lim b$ deformity alleles. Nature 346: 853-855.

MacGregor, G.R., L.D. Russell, M.E.A.B. Van Beek, G.R. Hanten, M.J. Kovac, C.A. Kozak, M.L. Meistrich, and P.A. Overbeek. 1990. Symplastic spermatids (sys): A recessive insertional mutation in mice causing a defect in spermatogenesis. Proc. Natl. Acad. Sci. 87: 5016-5020.

Mahon, K.A., P.A Overbeek, and H. Westphal. 1988. Prenatal lethality in a transgenic mouse line is the result of a chromosomal translocation. Proc. Natl. Acad. Sci. 85: 11651168.

Mangalam, H.J., V.R. Albert, H.A. Ingraham, M. Kapiloff, L. Wilson, C. Nelson, H. Elsholtz, and M.G. Rosenfeld. 1989. A pituitary POU domain protein, Pit-1, activates both growth hormone and prolactin promoters transcriptionally. Genes \& Dev. 3: 946-958.

Marks, S.C. 1984. Congenital osteopetrotic mutations as probes of the origin, structure and function of osteoclasts. Clin. Orthop. Rel. Res. 189: 239-263.

Marks, S.C. and P.W. Lane. 1976. Osteopetrosis, a new recessive lethal skeletal mutation on chromosome 12 of the mouse. $J$. Hered. 67: 11-18.

Martin, F.H., S.V. Suggs, K.E. Langley, H.S. Lu, J. Ting, K.H. Okino, C.F. Morris, I.K. McNeice, F.W. Jacobsen, E.A. Mendiaz, N.C. Birkett, K.A. Smith, M.J. Johnson, V.P. Parker, J.C. Flores, A.C. Patel, E.F. Fisher, H.O. Erjavec, C.J. Herrera, J. Wypych, R.K. Sachdev, I.A. Pope, I. Leslie, D. Wen, C.-H. Lin, R.L. Cupples, and K.M. Zsebo. 1990. Primary structure and functional expression of rat and human stem cell factor DNAs. Cell 63: 203-211.

Matsui, Y., K.M. Zsebo, and B.L.M. Hogan. 1990. Embryonic expression of a hematopoietic growth factor encoded by the S1 locus and the ligand for c-kit. Nature 347: 667-669.

McLaren, A., E. Simpson, K. Tomonari, P. Chandler, and H. Hogg. 1984. Male sexual differentiation in mice lacking $\mathrm{H}-\mathrm{Y}$ antigen. Nature 312: 552-555.

Mercer, J.A., P.K. Seperack, M.C. Strobel, N.G. Copeland, and N.A Jenkins. 1991. Novel myosin heavy chain encoded by murine dilute coat colour locus. Nature 349: 709-713.

Mercola, M. and C.D. Stiles. 1988. Growth factor superfamilies and mammalian embryogenesis. Development 102: 451460.

Mitrani, E., T. Ziv, G. Thomsen, Y. Shimoni, D.A. Melton, and A. Bril. 1990. Activin can induce the formation of axial structures and is expressed in the hypoblast of the chick. Cell 63: 495-501.

Nocka, K., J.C. Tan, E. Chiu, T.Y. Chu, P. Ray, P. Traktman, and P. Besmer. 1990a. Molecular bases of dominant negative and loss of function mutations at the murine c-kit/white spotting locus: $W^{37}, W^{\mathrm{v}}, W^{41}$, and $W . E M B O J .9: 1805-1813$.

Nocka, K., J. Buck, E. Levi, and P. Besmer. 1990b. Candidate ligand for the c-kit transmembrane kinase receptor: $\mathrm{KL}$, a fibroblast derived growth factor, stimulates mast cells and erythroid progenitors. EMBO 1. 9: 3287-3294.

Pavan, W.J., P. Hieter, and R.H. Reeves. 1990. Modification and transfer into an embryonal carcinoma cell line of a 360-kilobase human-derived yeast artificial chromosome. Mol. Cell. Biol. 10: 4163-4169. 
Pohl, T.M., M.-G. Mattei, and U. Ruther. 1990. Evidence for allelism of the recessive insertional mutation add and the dominant mouse mutation extra-toes $(X t)$. Development 110: 1153-1157.

Pollard, J.W., A. Bartocci, R. Arceci, A. Orlofsky, M.B. Ladner, and E.R. Stanley. 1987. Apparent role of the macrophage growth factor, CSF-1, in placental development. Nature 330: $484-486$.

Radice, G., J.J. Lee, and F. Costantini. 1991. Hß58, an insertional mutation affecting early postimplantation development of the mouse embryo. Development 111: 801-811.

Readhead, C., B. Popko, N. Takahashi, H.D. Shine, R.A. Saavedra, R.L. Sidman, and L. Hood. 1987. Expression of a myelin basic protein in transgenic shiverer mice: Correction of the dysmyelinating phenotype. Cell 48: 703-712.

Regenstrief, L.J. and J. Rossant. 1989. Expression of the c-fms protooncogene and of the cytokine, CSF-1, during mouse embryogenesis. Dev. Biol. 133: 284-294.

Reith, A.D., R. Rottapel, E. Giddens, C. Brady, L. Forrester, and A. Bernstein. 1990. W mutant mice with mild or severe developmental defects contain distinct point mutations in the kinase domain of the c-kit transmembrane receptor. Genes \& Dev. 4: 390-400.

Richa, J. and C.W. Lo. 1989. Introduction of human DNA into mouse eggs by injection of dissected chromosome fragments. Science 245: 175-176.

Rinchik, E.M. 1991. Chemical mutagenesis and fine structure functional analysis of the mouse genome. Trends Genet. 7: 15-21.

Riordan, J.R., J.M. Rommens, B.-S. Kerem, N. Alon, R. Rozmahel, Z. Grzelczak, J. Zielenski, S. Lok, N. Plavsic, J.-L. Chou, M.L. Drumm, M.C. Iannuzzi, F.S. Collins, and L.-C. Tsui. 1989. Identification of the cystic fibrosis gene: Cloning and characterisation of complementary DNA. Science 245: 1066-1072.

Rommens, J.M., M.C. Iannuzzi, B.-S. Kerem, M.L. Drumm, G. Melmer, M. Dean, R. Rozmahel, J.L. Cole, D. Kennedy, N. Hidaka, M. Zsiga, M. Buchwald, J.R. Riordan, L.-C. Tsui, and F.S. Collins. 1989. Identification of the cystic fibrosis gene: Chromosome walking and jumping. Science 245: 10591065.

Rosa, F.M. 1989. Mix.1, a homeobox mRNA inducible by mesoderm inducers, is expressed mostly in the presumptive endodermal cells of Xenopus embryos. Cell 57: 965-974.

Rossant, J. and A.L. Joyner. 1989. Towards a molecular-genetic analysis of mammalian development. Trends Genet. 5: 116120.

Russell, E.S. 1979. Hereditary anemias of the mouse: A review for geneticists. Adv. Genet. 20: 357-444.

Sarvella, P.A and L.B. Russell. 1956. Steel, a new dominant gene in the house mouse. J. Hered. 47: 123-128.

Schlessinger, D. 1990. Yeast artificial chromosomes: Tools for mapping and analysis of complex genomes. Trends Genet. 6: $248-258$.

Schnieke, A., K. Harbers, and R. Jaenisch. 1983. Embryonic lethal mutation in mice induced by retrovirus insertion into the $\alpha 1$ (I) collagen gene. Nature 304: 315-320.

Shawlot, W., M.J. Siciliano, R.L. Stallings, and P.A. Overbeek. 1989. Insertional inactivation of the downless gene in a family of transgenic mice. Mol. Biol. Med. 6: 299-307.

Sicinski, P., Y. Geng, A.S. Ryder-Cook, E.A. Barnard, M.G. Darlison, and P.J. Barnard. 1987. The molecular basis of muscular dystrophy in the $m d x$ mouse: A point mutation. Science 244: $1578-1580$.

Silvers, W.K. 1979. White-spotting, patch and rump-white. In The coat colors of mice: A model for gene action and inter- action pp. 206-241. Springer-Verlag, New York.

Simmons, D.M., J.W. Voss, H.A. Ingraham, J.M. Holloway, R.S. Broide, M.G. Rosenfeld, and L.W. Swanson. 1990. Pituitary cell phenotypes involve cell-specific Pit-1 mRNA translation and synergistic interactions with other classes of transcription factors. Genes \& Dev. 4: 695-711.

Sinclair, A.H., P. Berta, M.S. Palmer, J.R. Hawkins, B.L. Griffiths, M.J. Smith, J.W. Foster, A.-M. Frischauf, R. LovellBadge, and P.N. Goodfellow. 1990. A gene from the human sex-determining region encodes a protein with homology to a conserved DNA-binding motif. Nature 346: 240-244.

Smith, J.C., B.M.J. Price, K. Van Nimmen, and D. Huylebroeck. 1990. Identification of a potent Xenopus mesoderm-inducing factor as a homologue of activin A. Nature 345: 729-731.

Snell, G.D. 1929. "Dwarf," a new Mendelian recessive character in the house mouse. Proc. Natl. Acad. Sci. 15: 733-734.

Soriano, P., T. Gridley, and R. Jaenisch. 1987. Retrovirvses and insertional mutagenesis in mice: Proviral integration at the Mov-34 locus leads to early embryonic death. Genes \& Dev. 1: 366-375.

Stephenson, D.A., M. Mercola, E. Anderson, C. Wang, C.D. Stiles, D.F. Bowen-Pope, and V.M. Chapman. 1990. Plateletderived growth factor receptor $\alpha$ subunit gene $(P d g f r a)$ is deleted in the mouse patch $(\mathrm{Ph})$ mutation. Proc. Natl. Acad. Sci. 88: 6-10.

Sternberg, N., I. Ruether, and K. deRiel. 1990. Generation of a 50,000-member human DNA library with an average DNA insert size of 75-100 kbp in a bacteriophage P1 cloning vector. New Biol. 2: 151-162.

Stoye, J.P., S. Fenner, G.E. Greenoak, C. Moran, and J.M. Coffin. 1988. Role of endogenous retroviruses as mutagens: The hairless mutation of mice. Cell 54: 383-391.

Tan, J.C., K. Nocka, P. Ray, P. Traktman, and P. Besmer. 1990. The dominant $W^{42}$ spotting phenotype results from a missense mutation in the c-kit receptor. Science 247: 209-212.

Taylor, B.A. 1978. Recombinant inbred strains: Use in gene mapping. In Origins of inbred mice (ed. H. Morse), pp. 423438. Academic Press, New York.

Thomsen, G., T. Woolf, M. Whitman, S. Sokol, J. Vaughan, W. Vale, and D.A. Melton. 1990. Activins are expressed early in Xenopus embryogenesis and can induce axial mesoderm and anterior structures. Cell 63: 485-493.

Veres, G., R.A. Gibbs, S.E. Scherer, and C.T. Caskey. 1987. The molecular basis of the sparse fur mouse mutation. Science 237: 415-417.

Viskochil, D., A.M. Buchberg, G. Xu, R.M. Cawthon, J. Stevens, R.K. Wolff, M. Culver, J.C. Carey, N.G. Copeland, N.A. Jenkins, R. White, and P. O'Connell. 1990. Deletions and a translocation interrupt a cloned gene at the neurofibromatosis type 1 locus. Cell 62: 187-192.

Weiher, H., T. Noda, D.A. Gray, A.H. Sharpe, and R. Jaenisch. 1990. Transgenic mouse model of kidney disease: Insertional inactivation of ubiquitously expressed gene leads to nephrotic syndrome. Cell 62: 425-434.

Westphal, H. and P. Gruss. 1989. Molecular genetics of development studied in the transgenic mouse. Annu. Rev. Cell Biol. 5: 181-196.

Wiktor-Jedrzejczak, W., A. Ahmed, C. Szczylik, and R.R. Skelly. 1982. Hematological characterisation of congenital osteopetrosis in op/op mice. J. Exp. Med. 156: 1516-1527.

Wiktor-Jedrzejczak, W., A. Bartocci, A.W. Ferrante, A. AhmedAnsari, K.W. Sell, J.W. Pollard, and E.R. Stanley. 1990. Total absence of colony-stimulating factor 1 in the macrophagedeficient osteopetrotic (op/op) mouse. Proc. Natl. Acad. Sci. 87: 4828-4832.

Wilkie, T.M. and R.D. Palmiter. 1987. Analysis of the integrant 
in MyK-103 transgenic mice in which males fail to transmit the integrant. Mol. Cell. Biol. 7: 1646-1655.

Wilkinson, D.G., S. Bhatt, and B.G. Herrmann. 1990. Expression pattern of the mouse $T$ gene and its role in mesoderm formation. Nature 343: 657-659.

Williams, D.E., J. Eisenman, A. Baird, C. Rauch, V.K. Ness, C.J. March, L.S. Park, U. Martin, D.Y. Mochizuki, H.S. Boswell, G.S. Burgess, D. Cosman, and S.D. Lyman. 1990. Identification of a ligand for the c-kit proto-oncogene. Cell 63: 167174.

Woychik, R.P., T.A. Stewart, L.G. Lewis, P. D'Eustachio, and P. Leder. 1985. An inherited limb deformity created by insertional mutagenesis in a transgenic mouse. Nature 318: 3640.

Woychik, R.P., R.L. Maas, R. Zeller, T.F. Vogt, and P. Leder. 1990. "Formins": Proteins deduced from the alternative transcripts of the limb deformity gene. Nature 346: 850853.

Wright, M.E. 1947. Undulated: A new genetic factor in Mus musculus affecting the spine and tail. Heredity 1: 137-141.

Xiang, X., K.F. Benson, and K. Chada. 1990. Mini-mouse: Disruption of the pygmy locus in a transgenic insertional mutant. Science 247: 967-969.

Yanagisawa, K.O., H. Fuimoto, and H. Urushihara. 1981. Effects of the Brachyury (T) mutation on morphogenetic movement in the mouse embryo. Dev. Biol. 87: 242-248.

Yarden, Y., W.J. Kuang, T. Yang-Feng, L. Coussens, S. Munemitsu, T.J. Dull, E. Chen, J. Schlessinger, U. Francke, and A. Ullrich. 1987. Human proto-oncogene c-kit: A new cell surface receptor tyrosine kinase for an unidentified ligand. $E M B O$ \%. 6: 3341-3351.

Yoshida, H., S.-I. Hayashi, T. Kunisada, M. Ogawa, S. Nishikawa, H. Okamura, T. Sudo, L.D. Shultz, and S.-I. Nishikawa. 1990. The murine mutation osteopetrosis is in the coding region of the macrophage colony stimulating factor gene. Nature 345: 442-443.

Zdarsky, E., J. Favor, and I.J. Jackson. 1990. The molecular basis of brown, an old mouse mutation, and of an induced revertant to wild type. Genetics 126: 443-449.

Zeller, R., L. Jackson-Grusby, and P. Leder. 1989. The limb deformity gene is required for apical ectodermal ridge differentiation and anteroposterior limb pattern formation. Genes \& Dev. 3: 1481-1492.

Zsebo, K.M., J. Wypych, I.K. McNeice, H.S. Lu, K.A. Smith, S.B. Karkare, R.K. Sachdev, V.N. Yuschenkoff, N.C. Birkett, L.R. Williams, V.N. Satyagel, W. Tung, R.A. Bosselman, E.A. Mendiaz, and K.E. Langley. 1990a. Identification, purification and biological characterisation of hemopoietic stem cell factor from Buffalo rat liver-conditioned medium. Cell 63: 195-201.

Zsebo, K.M., D.A. Williams, E.N. Geissler, V.C. Broudy, F.H. Martin, H.L. Atkins, R.-Y. Hsu, N.C. Birkett, K.H. Okino, D.C. Murdock, F.W. Jacobsen, K.E. Langley, K.A. Smith, T. Takeishi, B.M. Cattanach, S.J. Galli, and S.V. Suggs. 1990b. Stem cell factor is encoded at the $S 1$ locus of the mouse and is the ligand for the c-kit tyrosine kinase receptor. Cell 63: $213-224$. 


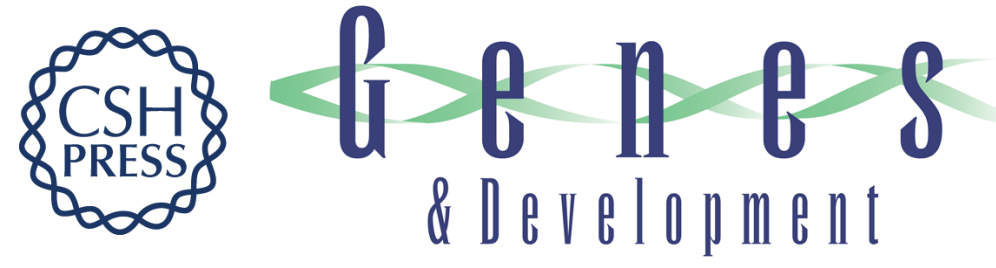

\section{Molecular basis of mouse developmental mutants.}

A D Reith and A Bernstein

Genes Dev. 1991, 5:

Access the most recent version at doi:10.1101/gad.5.7.1115

\section{References This article cites 128 articles, 45 of which can be accessed free at:} http://genesdev.cshlp.org/content/5/7/1115.full.html\#ref-list-1

\section{License}

Email Alerting

Receive free email alerts when new articles cite this article - sign up in the box at the top Service right corner of the article or click here.

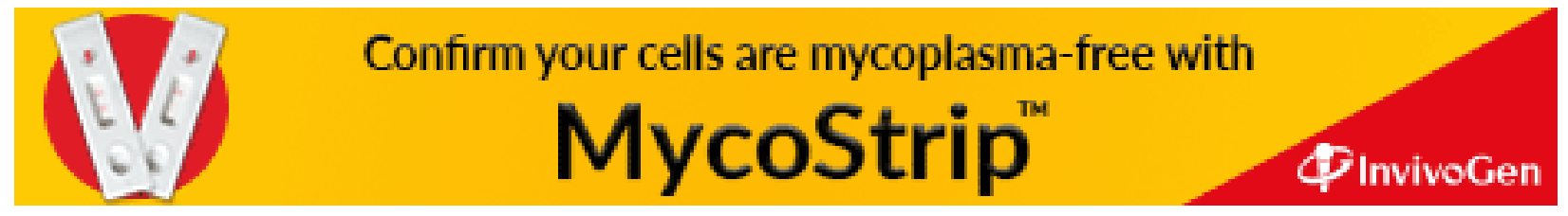

